\title{
PROCEEDINGS FOR CONSIDERATION OF CITIZEN'S APPEALS
}

Predmestnikov O. G.

\section{INTRODUCTION}

The development of the rule of law in Ukraine is inextricably linked with the strengthening and development of subjective rights and freedoms of citizens. In the implementation and protection of such rights and freedoms, one of the most important places is occupied by proposals, applications and complaints of citizens. At the same time, they play a role that guarantees the rule of law in public administration. The level of compliance with the rule of law in the state directly depends on the participation of law-abiding citizens in activities to support it. On the other hand, it is impossible not to agree that the presence of a large number of complaints about the actions of employees of the Executive apparatus is an alarming symptom, forcing us to closely analyze the state of Affairs in this apparatus and take measures to improve its work. One of the key areas of strengthening the rule of law is to improve the existing legislation, primarily administrative and procedural rules governing the exercise and protection of subjective rights and freedoms of citizens.

The main sources of information needed to address issues of state, economic and socio-cultural construction should include citizen's appeals as one of the most important means of exercising and protecting their rights. Appeals can relate to a variety of aspects of life and society-from the national interests of a particular person.

\section{The concept and types of appeals of citizens}

The appeal of citizens is considered as one of the ways to ensure legality and discipline in public administration. The attribution of this image to those by which it is possible to influence the state of law and discipline in the state is extremely important. The fact is that citizens ' appeals should be perceived as: a) a means of protection against violations of their rights, freedoms and legitimate interests by Executive authorities; b) the possibility of real influence on the activities of Executive authorities and officials; c) the opportunity to get a positive result for the citizen without the use of special legal knowledge for the registration of certain documents; d) the indicator of the formation of civil society ${ }^{1}$.

\footnotetext{
${ }^{1}$ Kuzmenko O. Course of administrative responsibility. Textbook./ed. Kuzmenko O. Kiev: Yurinkom inter, 2015. 568 p.
} 
Proposal (remark)-citizens ' appeal, where they Express advice, recommendation on the activities of state authorities and local selfgovernment bodies, deputies of all levels, officials, as well as opinions on the settlement of public relations and living conditions of citizens, improvement of the legal basis of state and public life, socio-cultural and other spheres of activity of the state and society.

Application (petition) - the appeal of citizens asking for assistance in the implementation embodied in the Constitution and current legislation rights and interests or violation of current legislation or drawbacks in activity of enterprises, institutions, organizations irrespective of forms of ownership, people's deputies of Ukraine, deputies of local councils, officials, as well as a statement of opinion regarding improvement of their activities. Petition - a written request for recognition of a person's relevant status, rights or freedoms, and the like.

The complaint-the appeal with the requirement about renewal of the rights and protection of legitimate interests of the citizens broken by actions(inactivity), decisions of state bodies, local governments, the enterprises, establishments, the organizations, associations of citizens, officials.

Decisions, actions (inaction), which may be appealed, in the field of public administration include the following, which violated rights and legal interests or freedoms of a citizen (group of citizens); created obstacles to the implementation of citizen's rights and legal interests or freedoms; illegal placed on the citizen any duties or illegally prosecuted ${ }^{2}$.

Requirements for applications:

1. Addressed to bodies and organizations, associations of citizens or officials, whose powers include the solution of the issues raised in the appeals.

2. The need to specify the surname, name, patronymic, place of residence of the citizen, statement of the essence of the issue, comments, suggestions, statements or complaints, requests or requirements.

3. Oral requests shall be a citizen and recorded by an official at personal reception and written sent by mail or handed over a citizen to the appropriate authority, the institution, personally or through authorized person.

Failure to comply with these requirements allows the subjects of power not to consider such appeals. In addition, under article 8 of the law of Ukraine "About addresses of citizens" not subject to review: re-treatment one and the same body by the same citizen on the same issue if the first is decided on the merits; complaints against the decision appealed against, if it is submitted to

2 Kuzmenko E. Administrative-procedural law of Ukraine: textbook / O. Kuzmenko, T. A. Gurzhiy; za zag. ed . Kyiv: Atika, 2007. 416 p. 
body or official of higher level after one year from the date of its adoption, but no later than one month from the time of familiarizing the citizen with the decision; appeals of persons recognized by the court as incapable.

An important factor to pay attention to is the period of consideration of applications. According to the requirements of the current legislation, appeals are considered and resolved within a period of not more than one month from the date of their receipt, and those that do not require additional studyimmediately, but not later than fifteen days from the date of their receipt. If within a month it is impossible to resolve the issue violated in the appeal, the head of the relevant body, enterprise, institution, organization or his Deputy shall establish the necessary period for its consideration, as reported to the person who filed the appeal. The General term of the decision of the questions raised in the address cannot exceed 45 days.

It should also be noted that in addition to the above types of appeals of citizens, the Law of Ukraine "on access to public information" allocates another type of appeal-a request for information.

Like other types of citizens ' appeals, the request for information can be individual or collective; it can be submitted orally, in writing or in another form (by mail, Fax, telephone, e-mail).

The request for information is submitted in a free form and must contain: 1) name (name) of the requestor, mailing address or email address, and the number of communications, if any; 2) General description of information or type, name, requisites or content of the document for which the request is made, if the questioner is known; 3) the signature and date, subject of the request in writing ${ }^{3}$.

The law clearly stipulates that a response to a request for information must be provided no later than five working days from the date of receipt of the request. If the request for information relates to information necessary to protect the life or freedom of a person regarding the state of the environment, the quality of food and household items, accidents, catastrophes, natural hazards and other extraordinary events that have occurred or may occur and threaten the safety of citizens, the response must be provided no later than 48 hours from the date of receipt of the request. And if the request concerns the provision of a large amount of information or requires the search of information among a significant amount of data, the term of consideration of the request may be extended to 20 working days with mandatory notification of the requester in writing not later than five working days from the date of receipt of the request.

${ }^{3}$ Scientific and practical commentary of the Code of Ukraine on administrative offences / G. Kalyuzhny, N. Inshin, I. Shopina, etc. - fifth Edition, with amendments and additions as of September 10, 2013 Kyiv: Alerta, 2013. 976 p. 
The request for information may be refused or delayed by the subject of authority. It is possible to refuse to provide information to a person if: - the information Manager does not own and is not obliged according to its competence provided by the legislation to own the information concerning which the request is made; - the information which is requested belongs to the category of information with limited access in accordance with part two of article 6 of this Law; - the person who submitted the request for information has not paid the actual expenses related to copying or printing stipulated by the legislation; - the requirements for the request for information have not been met.

A delay in the satisfaction of a request for information is allowed if the requested information cannot be provided for review within the time limits provided for by this Law in the event of force majeure. The decision on delay is brought to the attention of the requesting in writing with explanation of the order of the appeal of the made decision.

Public administration as a complex phenomenon, which is due to the regulatory influence of public administration in various spheres of public life, can be meaningful only if efficient mechanisms through which the public authorities receive information about its performance in the system of public administration through such means as monitoring, supervision and complaints of citizens, which today are combined as a way to ensure the legality and discipline ${ }^{4}$.

\section{Subjects of proceedings on citizens appeals}

The current legislation, law enforcement practice and theoretical research make it possible to confidently point out the existence of four types of participants in such legal relations, that is, 4 types of subjects of production on citizens ' appeals.

The first type (subjects, applicants) are persons whose applications are considered and on which decisions are made. These are capable citizens of Ukraine, foreigners and stateless persons who are in the territory of the state on legal grounds (unless otherwise provided by international treaties), whose treatment is not subject to article 8 of the Law of Ukraine "on citizens' appeals.

The second type (subjects considering appeals) includes subjects considering appeals and making decisions on them. Such are: public authorities; local governments; enterprises, institutions, organizations; associations of citizens; mass media; prosecutors (according to article 12 of

${ }^{4}$ Kuzmenko O. The Course of the administrative process: proc. benefit. / O. Kuzmenko; NAT. Acad. EXT. cases'. Kyiv: Yurinkom Inter, 2014. 207 p. 
The law of Ukraine "on Prosecutor's office" of October 5, 1991, the Prosecutor considers applications and complaints about violations of the rights of citizens and legal entities, except for complaints, consideration of which is referred to the competence of the court).

A common feature of the administrative-procedural status of these entities is that they cannot refuse to accept and consider appeals. The legislator establishes that appeals duly executed and filed in accordance with the established procedure are subject to mandatory acceptance and consideration.

It is prohibited to refuse to accept or consider a petition with reference to political views, party affiliation, gender, age, religion, nationality, citizen ignorance of the language.

If the issues raised in the appeal received by the authority are not included in the authority's powers, it shall be forwarded to the address within no more than five days. This is reported to the citizen who filed the appeal. If the address does not contain the data necessary for adoption of the proved decision by body or the official, it in the same term returns to the citizen with the corresponding explanations.

The third type (auxiliary subjects) are persons who contribute to the adoption of informed decisions. The law provides for their participation only in the processes of consideration of applications or complaints. The current legislation does not contain a special list of such persons.at the same time, the analysis of the Law of Ukraine "on citizens appeals" shows that such persons are a lawyer, a representative of the labor collective, a representative of an organization performing a human rights function, persons whose fault violations were committed, persons who provide information to the competent authorities during the verification of appeals in accordance with the requirements of articles 15 and 19. The peculiarity of this group of subjects is that the competence of auxiliary subjects is realized at the second stage of production - the stage of consideration of the application or complaint ${ }^{5}$.

The fourth type (patronage subjects) are persons who file an appeal in the interests of the citizen on his authority. The law provides for their participation in the processes of all types of appeals. It should be noted that their participation is regulated in detail in the proceedings on complaints. The peculiarity of this group of subjects is that the competence of patronage subjects is implemented at the 1st stage of production - the stage of filing an appeal. The patronage subjects include: legal representatives of minors and incapacitated persons, labor collectives, law-protective organizations, other persons, authorized persons.

5 Kolpakov V. Administrative-tort process: studies. Benefit./ Kolpakov V., Gordeev V. Kharkiv: Kharkiv legal, 2012. 227 p. 
The General features of the administrative-procedural status of subjects, for example, are: first, the obligation to fulfill a number of requirements. So, in the address the surname, a name, a patronymic, a residence of the citizen has to be specified, the essence of the raised question, remarks, offers, statements or complaints, requests or requirements is stated. Appeals are addressed to public authorities and local self-government, enterprises, institutions, organizations, regardless of ownership, associations of citizens or officials, whose powers include the solution of the issues raised in the appeals. The address issued without observance of these requirements, returns to the applicant with the corresponding explanations not later than in ten days from the date of its receipt; the obligation to bear responsibility for giving of addresses of illegal character. Thus, the law establishes that the submission by a citizen of an appeal containing slander and insults, discredit of state authorities, local self-government bodies, associations of citizens and their officials, heads and other officials of enterprises, institutions and organizations, regardless of ownership, calls for incitement to national, racial, religious hatred and other actions, entails responsibility under the current legislation; allocation in their array of two groups: Heroes of the Soviet Union, Heroes of Socialist Labor, invalids of the great Patriotic war and established that the proposals (comments) of this group of citizens are considered by the first heads of state bodies, local governments, enterprises, institutions and organizations personally; citizens who have benefits established by law and established that their appeals are considered as a priority ${ }^{6}$.

\section{Forms of work on ensuring consideration of citizens ' appeals}

Executive bodies, bodies of local self-government, heads of enterprises, institutions and organizations, regardless of ownership, should be strictly guided by the Constitution of Ukraine, the Law of Ukraine "on citizens appeals" of October 2, 1996 No. 393/96-BP, By presidential decree No. 109/2008 of 7 February 2008 "on priority measures to ensure the implementation and guarantee of the constitutional right to appeal to higherlevel state authorities and local self-government bodies" to ensure the creation of the necessary conditions for the realization of citizens' rights to a written appeal or personal reception and the mandatory receipt of a justified answer to it; to take prompt measures on the merits of the issues raised; to identify and eliminate the causes of complaints and statements of citizens, to decide

\footnotetext{
${ }^{6}$ Scientific and practical commentary of the Code of Ukraine on administrative offences / G. Kalyuzhny, N. Inshin, I. Shopina, etc. - fifth Edition, with amendments and additions as of September 10, 2013 Kyiv: Alerta, 2013. 976 p.
} 
questions of responsibility of officials, through whose fault the violations, the bureaucracy and red tape; to analyze the status of work with citizens and to inform the population; to consider the results of the analysis in practical work; - to actively use the experience of organization of the personal reception directly on the plants at the place of work and residence.

Today, almost all Central and local Executive authorities and local selfgovernment have special structural units to work with citizens' appeals, on the Internet pages of which information on the consideration of citizens' appeals, schedules of personal reception, analytical certificates and the like are submitted. The regional state administrations have established commissions for the consideration of citizens' appeals, commissions for the consideration of repeated appeals, "days of control" of the results of the execution of citizens ' appeals are held, exit receptions, helplines and so on are organized.

Another important mechanism for the implementation of citizens' rights to appeal is the institution of the Verkhovna Rada Commissioner for human rights (Ombudsman), which embodies parliamentary control over the observance of constitutional rights and freedoms of man and citizen. According to article 55 of the Constitution of Ukraine, "everyone has the right to apply for protection of their rights to the Commissioner of the Verkhovna Rada of Ukraine for human rights". According to article 16 of the Law of Ukraine "on the Commissioner of the Verkhovna Rada of Ukraine for human rights", the Commissioner carries out his activities on the basis of information about violations of human and civil rights and freedoms, which he receives from appeals of citizens of Ukraine, foreigners, stateless persons. Such appeals are accepted and considered by the Commissioner in accordance with the Law of Ukraine "on citizens' appeals",

Today, in the system of state bodies, such structures can be conditionally considered law enforcement agencies-the Prosecutor's office and internal Affairs bodies. However, the specificity of their work is that they consider the appeals of citizens in fact, when they are talking about a direct violation of the law. If the law is not violated, the appeal of citizens is not related to their competence. Thus, the issue of creating a separate state body for the purpose of comprehensive objective consideration and analysis of citizens' appeals under the patronage of the President of Ukraine becomes urgent.

It should be noted that the legislator gives special attention to the organizational actions taking place at the first stage of production. In order to provide citizens with an unhindered opportunity to apply, a special form of

\footnotetext{
${ }^{7}$ The code of Ukraine on administrative offences dated 7 December 1984, No. 8073-x URL.: http://zakon4.rada.gov.ua/laws/show/80731-10
} 
receiving proposals, applications and complaints - personal reception of citizens-is established and fixed at the legislative level.

Heads and other officials of public authorities, local governments, enterprises, institutions, organizations, associations of citizens, necessarily carry out such reception. The reception is held regularly on fixed days and hours, at a convenient time for citizens, at their place of work and residence. Reception schedules are brought to the attention of citizens. Heads of the specified structures define the order of reception of citizens.

Consideration of citizens "appeals under the" single window" system is carried out according to the scheme, which can be divided into a number of successive stages:

- advice on the procedure for filing an application and the timing of preparation of the necessary additional documents.

- check of correctness of registration of the application and the package of documents attached to the application;

- registration of the application in the electronic database and issuance to the applicant of an extract from the electronic journal confirming the acceptance of the application;

- formation and direction of inquiries in profile structures for the purpose of obtaining necessary data, coordination and conclusions concerning the decision of the question stated in the statement;

- control over the timing of individual requests and the total period of preparation of the response;

- registration of the prepared response and related documents in the electronic database;

- notification of the applicant;

- issue to the applicant of the answer, necessary documents for the solution of a question or the motivated refusal.

Transformation of the "single window" service multifunctional centers will receive citizens' appeals, provide a full range of public services for issuing documents to individuals, legal entities and individual entrepreneurs, as well as provide other related services to the population. In particular, an integral part of the work of such centers are consulting and reference services, Internet service, legal assistance and the like. Therefore, the creation of an extensive network of special bodies to work with citizens' appeals on a wide range of issues is a positive experience that is used in Ukraine ${ }^{8}$.

In the modern conditions of information society formation, measures within the framework of e-government development are seen as an important

\footnotetext{
${ }^{8}$ Administrative law : textbook / Y. Bytyak, etc. NAT. Yuri. Acad. Ukraine them. Yaroslav The Wise. Kharkiv: Pravo, 2010. 624 p.
} 
direction of increasing the efficiency of work with citizens ' appeals. It has become a common world practice to recognize certain legal force behind appeals transmitted through electronic communication systems.

With the introduction of an automated system of relations "citizen-state" can be counted on to improve the efficiency of public administration and limit corruption. Electronic interaction changes the very nature of government, making it more transparent and controlled by the public, because every citizen will be able to monitor the activities of public authorities and local governments, directly interact with public officials without queues and unnecessary bureaucracy.

Social information, which is in the appeals of citizens, is of great importance for improving the work of the authorities. As you know, the typical meaning of a phenomenon, trends in the development of practice can be recorded with sufficient certainty based on data analysis of a large number of facts that are in the appeals, their generalization. The analysis of such information allows drawing conclusions about the reasons and conditions, prompts ways of elimination of violations, mistakes, shortcomings, to make suggestions for improvement of business, legal response and other

\section{The concept and types of complaints. The ratio of the concepts of "complaint" and "appeal"}

The Constitution of Ukraine establishes the following important ways to protect rights and legitimate interests:

- the administrative and legal method of protection of the rights and freedoms of citizens, enshrined in article 40 of the Constitution of Ukraine, which provides that a citizen has the right to send individual or collective written appeals or personally appeal to state authorities, local self-government bodies and officials and officials of these bodies, who are obliged to consider the appeal and give a reasonable response within the period established by law. One such way is to exercise the right to file a complaint of citizens in administrative proceedings in connection with the violation of their rights and freedoms, including a complaint to the Prosecutor's office, the Commissioner of the Verkhovna Rada of Ukraine for human rights (part 2 of article 55 of the Constitution of Ukraine);

- judicial protection of rights and freedoms (article 55 of the Constitution of Ukraine), which is guaranteed to every citizen and is implemented in accordance with part 2 of article 1 of the Law of Ukraine "on the judicial system" in the forms of civil, economic, administrative, criminal and constitutional proceedings;

Common to all methods is a universal method of protection-appeal to the relevant authorities with a complaint. That is, it can be argued that by 
means of an administrative complaint it is possible to defend and defend, as well as to remove obstacles to the realization of any right or the satisfaction of any interest that does not contradict the General principles and current norms of law.

By means of the complaint in Ukraine it is possible to protect the rights and interests-public, special and office. By the way, not only those that are directly violated or infringed, but also those concerning which persons have doubts about their "non-violation" by public authorities, that is, a complaint filed in connection with possible violations.

This provision is certainly a positive element of the legal system of a democratic state and requires fixing in the legislation, especially in relation to an administrative complaint ${ }^{9}$.

Again, based on the meaning of legal institutions, it can be stated that the Institute of administrative complaints can be used by subjects in both positive management relations and in relations that are associated with coercive influence, including those associated with the use of punitive measures.

In the modern period of development of the legal system of Ukraine, the right to complain finally received legislative form.

The possibility of protecting the rights of citizens by filing a complaint is established by a significant number of acts, according to which a wide range of relevant officials are obliged to consider administrative complaints. The addressees of the complaint may be:

- President of Ukraine;

- Commissioner of the Riding Council for human rights;

- Executive authorities (including the highest) and their officials;

- bodies of Prosecutor's office of Ukraine;

- courts and other subjects authorized to consider complaints.

That is, it can be concluded that all actions for the final legal registration of an administrative complaint at the level of a real and effective way to protect the rights and interests of citizens in Ukraine have been formed.

"To serve as a means of protecting the rights and legitimate interests of citizens is one of the main functions ... right to appeal". That is why the right to a complaint should be considered from the position of legal guarantees, as a legal guarantee of the realization of human rights-it is important that not only citizens of Ukraine, but also foreign citizens, stateless persons, as well as all forms of their associations located on the territory of Ukraine ${ }^{10}$.

\footnotetext{
${ }^{9}$ Perepelyuk V. Administrative process. General part: Textbook / V. Perepelyuk. Kyiv: center of educational literature, 2004. 367 p.

10 Administrative justice. Administrative proceedings: studies.benefit. / T. Kolomoets, G. Gulevskaya, R. Sinelnik, I. Skvirsky. Kiev: Istina, 2007. 152 p.
} 
Thus, a complaint is an appeal of the subject of administrative and legal relations in the public administration (court) and its officials (judges), who are authorized to solve the administrative and legal dispute (within the established competence), in order to protect the subjective rights and interests that are violated or may be violated by the decisions, actions or inaction of the power subject of administrative and legal relations.

Types of complaints:

In the form of receipt: by mail; at a personal reception; through an authorized person; through authorities, through the media; from other bodies, institutions, organizations.

Based on income: primary; repeated; doublet; repeated; mass.

For the article the authors of references: men's; women's.

On the subject of: individual; collective; anonymous.

By type: telegram; letter; oral.

By category the authors of references: a war veteran; children of war; the invalid of the great Patriotic war; disabled veteran; combatant; a veteran of labor; group disability; group II disability; a disabled person of group III; a disabled child; single mother; a mother; a large family; a victim of the Chernobyl disaster; the participant of liquidation of consequences of Chernobyl accident; the Hero of Ukraine, Hero of the Soviet Union; Hero of Socialist Labor; child; other categories.

According to the social status of the authors of appeals: pensioner; worker; peasant; public sector employee; civil servant; soldier; entrepreneur; unemployed; student, student; Minister of a religious organization; a person deprived of liberty; a person whose freedom is limited; others.

By results of consideration: it is solved positively; it is refused satisfaction; explanations are given.

Treatment, returned to the author under articles and of the law of Ukraine "About addresses of citizens": the Appeal is forwarded to the facilities in accordance with article of the law of Ukraine "On appeals of citizens"; an Appeal is not subject to review in accordance with the articles of the law of Ukraine "On appeals of citizens".

The form of the complaint can be classified into administrative complaint; statement of claim.

The complaint and the administrative claim are specific forms of the address of physical and legal entities through which they pronounce own discontent with actions or inaction, decisions of public governing bodies and their officials. the Administrative claim (statement of claim) is in many respects similar to the administrative complaint, but similarity is external. In the administrative complaint, the claim element is contained in an underdeveloped form. Filing an administrative complaint does not make a 
citizen a party, does not stipulate his personal participation in the administrative process. "The Complainant," as rightly pointed out. Zagryatskov - - has no signs of the party in disputes about the right, he remains the person who asks". This position in legal relations takes the character of a vertical. The citizen waits for the decision on the complaint "from above". At the same time, filing a lawsuit in an administrative court leads to the emergence of original management relations: they are law enforcement and at the same time horizontal, in which subjects (citizenplaintiff and official-defendant) confront each other as equal parties. The plaintiff does not wait for "mercy" from above, but receives the decision of an independent and objective body. A natural or legal person dissatisfied with the actions (inaction) or decisions of the public administration takes a personal part in the process as a party. The right of administrative action is the right of a citizen to judicial protection in cases of violation of his subjective right in the field of public administration.

At the same time, it is necessary to dwell on the theoretical terms "complaint" and "appeal", as in the theoretical literature in practice, these terms are often used as synonymous ${ }^{11}$.

For the first time misunderstanding concerning these terms was brought by the legislator who in the Constitution of the USSR of 1977 used a turn not "the right to the complaint", and "the right to the appeal".

The concept of the complaint we have defined above, at the same time, the "appeal" is the law consistent procedure for submitting a complaint to public authority (court) and its officials (judges) who are empowered to resolve administrative-law dispute (within established authority), in order to protect subjective rights and interests that are violated or may be violating the decisions, actions or inaction of the power of the subject of administrative legal relations.

That is, an appeal is an activity to implement a public complaint. It should be noted that the order of implementation of the complaint depends on what body (official) the person addresses. Accordingly, the appeal of a person to a public management body is regulated by the legislation on citizens ' appeals, other normative-legal acts of the branch direction and lay the procedural basis for the consideration of positive cases of a managerial and service nature.

The appeal of subjects to administrative court with the statement of claim accepts the maintenance of administrative-procedural consideration of the address according to requirements of judicial process.

11 Administrative law: textbook / NU "YUAU im. Yaroslav the Wise"; for zag. ed: Y. Bytyak, V. Garashchuk, V. Zui. - 2nd view., rewritten. and extra. Kharkiv: Pravo, 2013. $656 \mathrm{p}$. 
Thus, consideration and resolution of complaints of individuals and legal entities is carried out by the public administration in a certain manner regulated by legal norms, through separate administrative and procedural proceedings.

\section{Structure of administrative proceedings on the complaint of individuals and legal entities}

Administrative and procedural proceedings on complaints of citizens in accordance belong to the group of procedural proceedings, as has the conditional name "on appeals of citizens".

In administrative and procedural proceedings on the complaint of a person, the following stages can be distinguished:

1) initiation of proceedings on the complaint;

2) checking the content of the complaint;

3) consideration and decision - making on the complaint;

4) appeal of the decision taken on the complaint to a higher authority (court). (Optional stage);

5) implementation of the decision on the complaint.

Let us consider in detail the content of these stages.

The law of Ukraine "About addresses of citizens" (article 16) defines the General rule, according to which, the complaint against actions or decisions of a public administration, enterprises, institutions, organizations, associations of citizens, mass media, officials is served in subordination order to higher body or official that does not deprive the citizen of the right to appeal to court in accordance with applicable law, and in the absence of such body or disagreement of the citizen with the decision on the appeal decision directly to the court.

The procedure of administrative appeal, in which the addressee of complaints is the Executive authority of the highest level (official), follows from the principles of functioning of the system of Executive authorities, namely-subordination, which implies the subordination of lower - level body's hierarchically higher bodies. Subordination and subordination, as elements of subordination, of the Executive authority of a lower level to a higher authority create for the latter an opportunity to influence the functioning of the subordinate authority, in particular, to change or cancel its decisions or oblige it to commit or terminate certain actions.

However, analyzing the content of the norm establishing a rule that the subject of the complaint stands Higher in the chain of command, the public authority (official) regarding the body (official) that made the decision, committed an act or made an omission, should indicate that it has the character rather of the norm-the principle than the norm-imperative, 
establishing a single possible behavior. According to the principle of action, such a rule is provided in art. 55 of the Constitution of Ukraine - "human and civil rights and freedoms are protected by the court", which does not exclude the possibility of the protection of human and civil rights and other authorized bodies. That is why the subject of the complaint may be not only higher as subordination body (official), the body (official) decisions, actions or omissions which are appealed, if the subject of application that addresses their requirements. Often, the appeal to the body (official), the decision, actions or inaction of which are appealed, allows to ensure, firstly, a qualified examination of the complaint, since the Executive authority is already familiar with the case and, secondly, helps to remove the conflict between the authority and the person, which is important for the formation of positive relations between these subjects.

The complaint may be filed orally or in writing. Oral complaints are stated by the citizen and fixed by the official on personal reception of citizens. The duty for heads and other officials of Executive authorities to carry out personal reception of citizens is fixed in Art. 22 of the Law of Ukraine "About addresses of citizens".

Any documents and other materials relating to the issues raised in the appeal may be attached to the Complainant's written application.

Anonymous appeal is registered, but is not subject to consideration and filed in the case of the nomenclature of cases. The decision on recognition of the address anonymous and leaving it without consideration is made by the Chairman of public body on representation of the head of Department of organizational and documentary maintenance or other official of public body authorized on record keeping on addresses of citizens.

All citizens' complaints received by public authorities must be accepted, previously considered and centrally registered on the day of their receipt in the manner prescribed By the instruction on record-keeping on citizens' appeals in state and local authorities, associations of citizens, enterprises, institutions, organizations, regardless of ownership, in the media, approved by the resolution of the Cabinet of Ministers of Ukraine of 14 April 1997 No. 348.

Thus, all complaints received should be accepted and centrally registered on the day of their receipt on registration and control cards suitable for processing by personal computers, or in journals. Envelopes (clippings from them) are stored together with the complaint. Registration of personal reception of citizens is conducted on cards, in magazines or by means of electronic computer equipment.

The journal form of registration of offers, applications and complaints and the account of personal reception of citizens is allowed in the organizations 
with annual volume of receipt to 600 offers, applications and complaints and the same number of addresses of citizens on personal reception.

Written complaints filed at a personal reception are also subject to centralized registration on registration and control cards suitable for processing by personal computers, or in journals ${ }^{12}$.

Automated registration of complaints and registration of personal reception of citizens are carried out from the registration and control forms by entering into a personal computer the following elements: date of receipt of the appeal; surname, name, patronymic, category (social status) of the applicant; where the appeal was received, date, index, control; issues raised-summary, indices; content and date of resolution, surname of the author, performer, deadline; date of dispatch, index, content of the document, decisions taken, date of removal from control; case number on the nomenclature.

An official authorized to conduct record keeping on citizens' appeals carries out preliminary consideration of citizens' complaints in public administration bodies.

Preliminary consideration includes verification of correctness of registration, acquaintance with the contents, and determination of the order of further work on the complaint of the citizen (citizens).

The applicant (s) with the date must sign the written complaint.

A complaint filed without complying with these requirements shall be registered and returned to the Complainant with the relevant explanations no later than five days from the date of its receipt. A copy of such complaint and a copy of the letter of explanation, which returned the complaint to the applicant, remains in the body to which the applicant applied. The decision to return the appeal to the Complainant is made by the head of the authority ${ }^{13}$.

Repeated complaints by the same body from the same citizen on the same issue are not considered, if the first is resolved in fact, as well as complaints that are filed in violation of the terms provided for in article 17 of the Law of Ukraine "on citizens "appeals" and complaints of persons recognized by the court as incapable.

At the request of a citizen who filed a complaint with the organization, on the first sheet of a copy of the appeal, a stamp is stamped indicating the name of the organization, the date of receipt and the incoming number of the appeal. Such copy is returned to the citizen.

${ }^{12}$ Scientific and practical commentary of the Code of Ukraine on administrative offences / G. Kalyuzhny, N. Inshin, I. Shopina, etc. - fifth Edition, with amendments and additions as of September 10, 2013 Kyiv: Alerta, 2013. 976 p.

${ }^{13}$ Administrative and legal protection of citizens ' rights: studies.-method. possib. / [Col. K. Afanasiev et al.]; Lugano. state University EXT. cases to them. E. Didorenko. Lugansk : RIO LGUSD them. E. Didorenko, 2011. 279 p. 
Complaints containing issues that are not within the competence of a public body shall be forwarded to the relevant body competent for consideration within five days after its registration, and the Complainant shall be notified thereof at the same time, with an explanation of the grounds for submitting the complaint. The decision to forward the complaint by affiliation is made by the head of the public body or his Deputy in accordance with the distribution of functional responsibilities. The copy of the complaint of the citizen remains in business of public body, which forwarded the original of the address on accessory to the corresponding body.

The complaint is sent by mail or transmitted to the appropriate body by a citizen personally or through an authorized representative, if his powers are issued in accordance with the current legislation.

In addition, according to the content of the Law of Ukraine "on electronic documents and electronic document management" of 22.05.2003, the complaint can be sent (filed) in electronic form with mandatory compliance with the requirements for its details and requirements for the submission of electronic documents.

According to article 5 of the Law of Ukraine "on electronic documents and electronic document circulation", an electronic document is a document in which information is recorded in the form of electronic data, including mandatory document details. This Law (article 8) provides that the legal force of an electronic document cannot be rejected solely because it has an electronic form. The author or the intermediary in electronic form by means of information, telecommunication, and information and telecommunication systems or by sending electronic carriers on which this document is recorded carries out Sending and transmission of electronic documents.

Citizens have the right to file complaints with the public administration or its officials in Ukrainian or another language acceptable to the parties. A citizen may file a complaint in person or through another person authorized to do so. Complaints may be filed in the interests of citizens by a labor collective, an organization engaged in human rights activities, or another person, if their powers are issued in accordance with the procedure established by law.

The complaint shall be accompanied by the decisions available to the citizen or copies of the decisions that were taken on his appeal earlier, as well as other documents necessary for the consideration of the complaint, which after its consideration shall be returned to the citizen ${ }^{14}$.

14 Administrative law of Ukraine. Vol. 1: General administrative law: textbook: in 2 volumes / Galunko V. et al. Kherson: PJSC "Kherson city printing house", 2017.320 p. 
The prohibition of refusal to accept and consider complaints with reference to political views, party affiliation, gender, age, ignorance of the language of the appeal. At the same time, it should be noted that the legislation still establishes some restrictions on the age of persons who have the right to file complaints independently. For example, in the interests of minors, their legal representatives file complaints. The same procedure is provided for filing complaints and in the interests of incapacitated persons.

Complaints duly executed and filed in accordance with the established procedure are subject to mandatory acceptance and consideration. Each complaint must be made one of these decisions:

- take to production;

- submit the decision to a subordinate body or institution. At the same time, it is forbidden to send citizens ' complaints for consideration to those bodies or officials whose decisions, actions or inactivity are being appealed;

- transfer by affiliation to another office, if the issues raised in the complaint are not within the competence of the body that received the complaint, which is simultaneously reported to the subject of the appeal;

- to leave without consideration, in the presence of the bases defined by the law.

A written complaint is logged, it is exposed retrace control card, which is the main accounting document written request of a citizen, which gradually, as the consideration of the application is filled in such information, in particular:

a) registration index and date of receipt of the complaint;

b) surname, name and patronymic of the citizen;

c) address of the citizen;

d) the name of the public authority, other bodies, institutions, organizations, mass media, the surname and initials of the authorized person complaining in the interests of the applicant, the outgoing number and date of the letter to which the complaint was sent;

e) summary of the complaint;

f) resolution of the head of the public body;

f) date and grounds for refusal to consider the complaint or termination of consideration, position, surname and initials of the official who made this decision;

g) data on bringing the complaint to the executors and moving the complaint in accordance with the subordination;

h) the outgoing number and date of the letter by which the complaint, the decision of which is not within the competence of the public authority, was sent for consideration to another body; 
i) information about the requests sent during the complaint (where or to whom they were sent, dates and outgoing numbers of requests, registration numbers and dates of responses received);

j) results of consideration of the complaint, date and outgoing number of the answer to the citizen;

k) the case number in which the complaint is stored;

1) data on the receipt of repeated and duplicate complaints.

The head of a public body is obliged to find out the reasons for the receipt of a repeated complaint of a citizen. If it is caused by violation of the established order of consideration, the officials who have allowed violation of the rights of the citizen bear responsibility according to their job descriptions and the legislation of Ukraine.

Written complaints of citizens addressed to the head of a public body shall be subject to mandatory consideration by the head of a public body (an official performing his duties) or Deputy heads of a public body in accordance with their powers in order to determine whether the issues raised in these complaints fall within the competence of public bodies;

Appeals of women who are awarded the honorary title of Ukraine "Mother-heroine", Heroes of Ukraine, Heroes of the Soviet Union, Heroes of Socialist Labor, invalids of the great Patriotic war are taken under personal control and are considered by the heads of public bodies personally.

Citizens' complaints are sent to the head of the public body or his deputies for consideration on the day of their receipt.

Repeated and duplicate complaints received after the processing of the primary complaint are submitted for consideration together with the materials of the primary complaint ${ }^{15}$.

It is prohibited to entrust the consideration of a citizen's complaint to an official whose decision, action or inaction is being appealed.

Decisions taken on complaints must be motivated and based on the norms of the legislation and brought to the attention of the applicant. The official, having recognized the complaint subject to satisfaction, is obliged to provide timely and correct execution of the made decision, and in case of recognition of a question of the complaint reasonable - to take measures to restoration of the violated rights of citizens.

When considering complaints, special attention is paid to solving problems faced by war and Labor veterans, disabled people, citizens affected by the Chernobyl disaster, large families, single mothers and other citizens in need of social protection and support.

${ }^{15}$ Administrative procedural law of Ukraine: Textbook. / Edited by O. V. Kuzmenko. Kyiv: Atika, 2007. 416 p. 
It should be noted that at any stage of consideration of the complaint, the public body (official) must ensure the subject of the appeal and other participants of administrative proceedings the implementation of their procedural rights. According to the Law of Ukraine "on citizens' appeals" the subject of the appeal has the following rights:

- personally present the arguments to the person who checked the complaint, and participate in the verification of the complaint;

- to get acquainted with materials of check;

- submit additional materials or insist on their request by the body that considers the complaint;

- to be present at consideration of the complaint;

- to use the services of a lawyer or a representative of a labor collective, an organization that performs a human rights function, having issued this authority in accordance with the procedure established by law;

- receive a written response on the outcome of the complaint;

- to Express orally or in writing the requirement about observance of secrecy of consideration of the complaint;

- claim damages if they were the result of violations of the established procedure for consideration of complaints.

The specified volume of procedural rights of the subject of the address as a whole is sufficient for realization of its legitimate interests in the process of consideration of complaints. At the same time, in our opinion, the subject of the appeal should have the right to demand compensation not only for those losses that resulted from violations of the established procedure for consideration of complaints, but also those that were caused due to nonexecution or improper execution of decisions on the complaint.

In turn on the subject of the decision of the case the following duties are assigned:

- objectively, comprehensively and on time to check complaints;

- in case of adoption of the decision on restriction of access of the citizen to the relevant information at consideration of the complaint to make about it the reasoned resolution;

- at the request of a citizen to invite him to a meeting of the relevant body considering his complaint;

- to cancel or change the appealed decisions in the cases provided by the legislation of Ukraine if they do not meet the law or other normative acts, immediately to take measures to the termination of illegal actions, to reveal, eliminate the reasons and conditions promoting offenses;

- to ensure the restoration of violated rights, the real implementation of the decisions taken in connection with the complaint;

- to inform in writing to the citizen about results of check of the complaint and an essence of the made decision; 
- to take measures regarding the compensation in the manner prescribed by law material losses if they were caused to a citizen as a result of infringement of his rights or legal interests, decide issues on responsibility of persons, through whose fault the violation has taken place, and at the request of the citizen not later than within a month to bring the decision to the attention of the local authority, labor collective or Union of citizens at citizen's place of residence;

- in case of recognition of the statement or the complaint unreasonable, to explain an order of the appeal of the decision made on it;

- to prevent unjustified transfer of complaints to other bodies;

- to organize and check the status of consideration of citizens' complaints, to take measures to eliminate the causes that give rise to them, to systematically analyze and inform the population about the progress of this work.

This list of duties of the subject of the resolution of the case should be supplemented by the obligation to familiarize the participants of administrative proceedings with their procedural rights and obligations, which would be an additional guarantee of their implementation in this production ${ }^{16}$.

At the same time, it is necessary to emphasize an important feature that characterizes the content of the complaint proceedings. It is manifested in the fact that the specified production is characterized by clearly defined deadlines.

So, the term of consideration of the complaint of citizens is calculated from the day following the day of registration of the complaint in public body, on the day of registration to the Complainant of the answer to his complaint. If the last day of the term of consideration of the complaint falls on a nonworking day, the last day of the term is the first working day after it.

Complaints are considered and decisions are made on them within a period of not more than one month from the date of their receipt, taking into account weekends, holidays and non-working days, and those that do not require additional study and verification on them - immediately, but not later than 15 days from the date of their registration.

If it is impossible to resolve the issues raised in the complaint within a month, the head of the relevant public body or his Deputy shall set the time required for consideration of the appeal, as reported to the person who filed it. At the same time, the total term for resolving the issues raised in the appeal may not exceed 45 days. The specified terms are settled In. 17 of the Law of Ukraine "on citizens' appeals", which notes that a complaint against a decision, appealed, may be filed with a body or an official of the highest level within one year from the date of its adoption, but not later than one month

${ }^{16}$ Administrative procedural law of Ukraine: Textbook. / Edited by O. V. Kuzmenko. Kyiv: Atika, 2007. 416 p. 
from the time of familiarization of the citizen with the decision. Complaints filed in violation of the deadline are not considered.

At the same time it should be noted that the term of the administrative appeal provided by Art. 17 of the Law of Ukraine "on citizens' appeals" contradicts Art. 289 of the Code of Ukraine on administrative offenses, where it is determined that the complaint against the decision in the case of an administrative offense can be filed within ten days from the date

At the same time, certain provisions establish the possibility of increasing the time for consideration of complaints. So, for example, in the order of consideration of appeals and personal reception of citizens in the State customs service of Ukraine, other customs authorities, specialized customs institutions and organizations it is specified that in case of impossibility owing to objective reasons of performance in due time of the instruction of the head (Deputy head) of customs body on consideration of the address this term can be extended by the head (Deputy head) of customs body which provided the instruction. Thus the head of division-executor in advance, but not later than five days before the end of term, reports on it to the head (the Deputy head, charged to consider addresses) of customs authority and raises a question of extension of term of execution of the order within the terms established by the legislation on addresses of citizens. In this case, the applicant no later than one day before the expiration of the previously defined period of consideration of the appeal is sent a written notice of the extension of the period of consideration of the appeal with reasoned explanations.

At the same time, in the Instruction on the order of consideration of addresses and personal reception of citizens in bodies of the state tax service it is specified that the complaint against the decision appealed, can be submitted to body of The state tax service of the highest level within one year from the moment of its acceptance, but not later than one month from the time of acquaintance of the citizen with the made decision. Complaints filed in violation of the specified period, the State tax authorities are not considered.

To resolve these differences, it is necessary either to establish a single deadline for filing complaints, or to stipulate in the Law of Ukraine "on citizens' appeals" the possibility of establishing other deadlines for appeal in legislative acts.

Complaints filed in violation of the term specified in the law are not considered. At the same time, separate normative legal acts establish that if the deadline for filing complaints is missed for a good reason, the body or official considering the complaint can restore it.

For example, in the Instruction on the procedure for consideration of appeals and personal reception of citizens in the state tax service, it is indicated that the State tax service body considering the complaint can restore 
the time missed for a good reason. That is, the specified norm violates the rule of conduct established in art. . 8 of the Law of Ukraine "on citizens" appeals". At the same time, from the point of view of democratic principles of formation of the legislation it is impossible to forbid consideration of complaints, which term of submission, is missed for the objective reasons. Therefore, in our opinion, the specified article demands editing in the following: "the address of citizens which deadline is passed for the objective reasons can be renewed by the body considering the address".

It should be noted that when considering a complaint, it is prohibited to disclose information about citizens and the content of the complaint to persons not involved in the implementation of the complaint.

The answer on results of consideration of the complaint without fail is provided by that public body which received it and which competence includes the decision of the questions raised in the complaint, under the signature of heads or persons to whom the right to make the signature is provided by the head of public body.

The decision on refusal in satisfaction of the requirements or requests stated in the complaint is brought to the attention of the citizen in writing with reference to the current legislation and statement of motives of refusal, and with explanation of the order of the appeal of the made decision. The measures taken by the public authority to verify the complaint are indicated.

The complaint is considered fully processed if considered all its questions, made an informed decision and taken the necessary measures to address the issues raised and the applicants notified of the outcome of the complaint and the decision.

It should be noted that the legislation establishes the obligation to generalize the content of complaints, critical comments that they contain in order to timely identify the causes that lead to violations of the rights and interests of citizens, study public opinion, improve the work of public administration. Special attention is paid to the elimination of the causes that cause repeated and collective complaints, as well as forcing citizens to contact the public authorities, the media on issues that can and should be considered by the public administration on the spot. According to the results of the analysis, an analytical report with specific proposals for further improvement of the organization of work with citizens ' appeals is necessarily drawn up.

At the same time it should be noted that in modern conditions of information society formation an important direction to enhance the efficiency of work with citizens 'complaints are measures in the framework of e-government development. A common world practice has become the recognition of appeals (including complaints) transmitted through electronic communication systems, a certain legal force. 
Thus, in the United States, government officials are required to receive and process citizens' letters sent to the authorities by e-mail, and to give official answers to them. The Scottish Parliament has an electronic appeals system (e-petitioning), which allows each citizen to promptly propose any issue for consideration. All requests are considered and a response is prepared for each. The UK Parliament introduces a similar system. In 2008, this way more than $7 \%$ of the citizens of the state addressed to the Parliament with their complaints and proposals. In 2002 in the Italian city of Bologna, a special decree was issued, which instructed the city Executive authorities to actively use the advice of citizens expressed at the municipal Internet forum, to answer questions, as well as based on messages to highlight and analyze pressing problems. A slightly different scheme was used in the city of Modena, where instead of a forum; a system of the so-called electronic newssheet (newsletter) was created. Leaving your personal data, the citizen was able to regularly obtain on their own e-mail address information about the plans of the city Council, ask questions via email and receive answers in the statutory period, to complain of actions of officials and get an answer on the merits. In addition, a number of online counselling centers have been set up and online surveys have been conducted. Similar experiments were also conducted at the local government level in other Italian cities ${ }^{17}$.

With the introduction of an automated system of relations "citizen-state" can be counted on to improve the efficiency of public administration and limit corruption. Electronic communication can change the very nature of government, make it more transparent and controlled by the public, because every citizen will be able to monitor the activities of the public administration, directly interact with government officials without queues and unnecessary bureaucracy.

Therefore, the development of such a form of work with citizens 'complaints as electronic complaints via the Internet and e-mail should be considered not as an auxiliary, but as one of the main directions in the field of improving the work with citizens' complaints and overcoming corruption [3].

\section{Legal liability for violation of the legislation on citizens' appeals}

The structure of the system of work with citizens 'appeals is incomplete without considering the issue of legal liability for violation of the legislation on citizens' appeals.

As a General rule, prosecution for violation of the legislation on citizens' appeals takes place in accordance with the current legislation on

\footnotetext{
${ }^{17}$ Demsky E. Administrative procedural law of Ukraine: studies. no. / E. F. Demsky. Kyiv: Yurinkom Inter, 2008. 496 p.
} 
administrative, criminal and civil liability. That is, it will depend on the features of the offense, the importance of the issue, the complexity and severity of the act.

Legal liability for violation of the legislation on citizens' appeals can be divided into:

1) legal liability of officials;

2) legal responsibility of citizens.

Article 24 of the Law of Ukraine "on citizens' appeals" provides for civil, administrative or criminal liability for persons guilty of violating the legislation on citizens' appeals, provided for by the legislation of Ukraine.

Citizens have the right to recovery of the material (monetary) losses caused to them by illegal actions of the officials who took part in consideration of addresses of citizens or directly solved business. Such cases are decided in court. Note that you do not need to "fear" the trial; remember that according to the Constitution of Ukraine, the court is the main guarantor of the protection of citizens' rights. Article 55 of the Constitution of Ukraine establishes the right of everyone to appeal against decisions, actions or inactivity of public authorities, local authorities, officials and officials.

In the case of satisfaction of complaint, body or official person who has accepted an illegal decision concerning application of the citizen, reimburse him for the damage associated with the submission and consideration of complaint, reasonable expenses incurred in connection with the departure for the consideration of the complaint at the request of the relevant body, and lost during this time earnings. Disputes on recovery of expenses are considered in court.

A citizen at his request and in accordance with the procedure established by the current legislation may be compensated for moral damages caused by unlawful actions or decisions of the body or official when considering a complaint. The amount of compensation for moral (non-property) losses in monetary terms is determined by the court (article 25 of the Law of Ukraine “on citizens' appeals").

Material losses may include both costs associated with travel for consideration of the complaint by the relevant authority, and lost earnings, lost income during this time. Non-pecuniary damage can be more substantial for monetary as it concerns physical and mental health. The amount of compensation for moral damage in monetary terms is determined by the court. Moral harm is recognized that it led to moral suffering, loss of normal life relationships, the cost of additional efforts to organize their lives. The characteristics of moral harm are contained in the resolution of the Plenum of the Supreme Court No. 4 of 31 March 1995 "on judicial practice in cases of 
compensation for moral (non-property) harm". In particular, moral damage includes loss or humiliation of a person's business reputation.

The law of Ukraine" on citizens' appeals" also provides for the responsibility of citizens for filing appeals of an illegal nature. Thus, article 26 of this law States that the submission by a citizen of an appeal containing slander and insults, discredit of public authorities, local self-government bodies, associations of citizens and their officials, heads and other officials of enterprises, institutions and organizations, regardless of ownership, calls for incitement to national, racial, religious hatred and other actions, entail responsibility under the current legislation.

The legislation also provides for property liability of citizens. In particular, expenses incurred by a public authority, local self-government, institution, organization, regardless of ownership, associations of citizens, enterprise, mass media in connection with the verification of appeals containing false information may be recovered from citizens by a court decision (article 11 of the Law of Ukraine “on citizens' appeals).

It should be noted that the legislation does not directly provide for liability for specific offenses in the process of consideration of appeals, and the articles of the Law of Ukraine "on citizens' appeals" do not define sanctions for relevant violations, which, undoubtedly, is a serious drawback of the current legislation.

\section{CONCLUSIONS}

Thus, the Law of Ukraine "About addresses of citizens" (article 16) defines the General rule, according to which, the complaint against actions or decisions of a public administration, enterprises, institutions, organizations, associations of citizens, mass media, officials is served in subordination order to higher body or official that does not deprive the citizen of the right to appeal to court in accordance with applicable law, and in the absence of such body or disagreement of the citizen with the decision on the appeal decision directly to the court.

The procedure of administrative appeal, in which the addressee of complaints is the Executive authority of the highest level (official), follows from the principles of functioning of the system of Executive authorities, namely-subordination, which implies the subordination of lower - level bodies' hierarchically higher bodies. Subordination and subordination, as elements of subordination, of the Executive authority of a lower level to a higher authority create for the latter an opportunity to influence the functioning of the subordinate authority, in particular, to change or cancel its decisions or oblige it to commit or terminate certain actions. 


\section{SUMMARY}

Constitutional provision of citizens to appeal. The concept of production on appeals of citizens. Place of production on citizens' appeals in the administrative process. The legal basis of the proceedings on the treatment of citizens. Term of consideration of citizens' appeals. Forms and types of appeals of citizens. Requirements for treatment. Appeals that are not subject to consideration and decision. Stages of production on appeals of citizens. Responsibility for violation of the legislation on citizens' appeals.

The concept and types of administrative appeal. Appeal in administrative procedure. Deadline for filing a complaint. Decisions, actions (inaction) that can be appealed. Judicial appeal of actions and decisions of subjects of power. Administrative justice as a form of judicial protection of human and civil rights and freedoms in the sphere of Executive power. Functions and powers of administrative courts. Types of proceedings in administrative courts. Subject of appeal in administrative courts. Characteristics and types of proceedings in cases of administrative appeal.

\section{REFERENCES}

1. Administrative justice. Administrative proceedings: studies.benefit. / T. Kolomoets, G. Gulevskaya, R. Sinelnik, I. Skvirsky. Kiev: Istina, 2007. $152 \mathrm{p}$.

2. Administrative law: textbook / Y. Bytyak, etc. NAT. Yuri. Acad. Ukraine them. Yaroslav the Wise. Kharkiv: Pravo, 2010. 624 p.

3. Administrative law of Ukraine. Vol. 1: General administrative law: textbook: in 2 volumes / Galunko V. et al. Kherson: PJSC "Kherson city printing house", 2017. $320 \mathrm{p}$.

4. Administrative procedural (judicial) law of Ukraine: Studies. / Odessa national law Academy / S. Kivalov (ed.). Odessa: Legal literature, 2007. 312 p.

5. Administrative and legal protection of citizens' rights: studies.-method. possib. / [Col. K. Afanasiev et al.]; Lugano. State University EXT. cases to them. E. Didorenko. Lugansk: RIO LGUSD them. E. Didorenko, 2011. 279 p.

6. Administrative procedural law of Ukraine: Textbook. / Edited by O. V. Kuzmenko. Kyiv: Atika, 2007. 416 p.

7. Bandurka O. Administrative process: Textbook for the University / O. Bandurka, M. Tishchenko. Kiev: Litera LTD, 2002. 286 p.

8. Demsky E. Administrative procedural law of Ukraine: studies. no. / E. F. Demsky. Kyiv: Yurinkom Inter, 2008. 496 p.

9. Kolpakov V. Administrative responsibility (administrative-tort law): Textbook / V. Kolpakov. Kyiv: Yurinkom Inter, 2008. 256 p. 
10. Kolpakov V. Administrative-tort process: studies. Benefit. I Kolpakov V., Gordeev V. Kharkiv: Kharkiv legal, 2012. 227 p.

11. ComSoc A. Administrative process of Ukraine: textbook/ ComSoc A. Bevzenko, R. Miller. Kiev: A Precedent, 2007. 531 p.

12. Kuzmenko E. Administrative-procedural law of Ukraine: textbook / O. Kuzmenko, T. Gurzhiy; za zag. ed . Kyiv: Atika, 2007. 416 p.

13. Kuzmenko O. Administrative justice in Ukraine: textbook / O. Kuzmenko. Kyiv: Atika, 2007. 156 p.

14. Kuzmenko O. The Course of the administrative process: proc. benefit. / O. Kuzmenko; NAT. Acad. EXT. cases'. Kyiv: Yurinkom Inter, 2014. 207 p.

15. Perepelyuk V. Administrative process. General part: Textbook / V. Perepelyuk. Kyiv: center of educational literature, 2004. 367 p.

16. Administrative law: textbook / NU "YUAU im. Yaroslav the Wise"; for zag. ed: Y. Bytyak, V. Garashchuk, V. Zui. 2nd view., rewritten. and extra. Kharkiv: Pravo, 2013. 656 p.

17. Administrative procedural law: studies. no. / Dnepropetr. state University EXT. del; for zag. ed. Kharkiv: Pravo, 2013. $352 \mathrm{~s}$.

18. The code of Ukraine on administrative offences dated 7 December 1984, No. 8073-x URL: http://zakon4.rada.gov.ua/laws/show/80731-10

19. Course of administrative law of Ukraine: Textbook / V. Kolpakov, O. Kuzmenko, I. Pastukh -2nd ed., redistribution. and extra. Kyiv: Yurinkom Inter, 2013. $872 \mathrm{p}$.

20. Scientific and practical commentary of the Code of Ukraine on administrative offences / G. Kalyuzhny, N. Inshin, I. Shopina, etc. - fifth Edition, with amendments and additions as of September 10, 2013 Kyiv: Alerta, 2013. 976 p.

21. Kuzmenko O. Course of administrative responsibility. Textbook./ed. Kuzmenko O. Kiev: Yurinkom inter, 2015. 568 p.

\section{Information about the author: Predmestnikov O. G., Doctor of Law, Professor,} First Deputy Head of the Main Territorial, Department of Justice in the Kherson Region 42/14, Potiomkinska str., Kherson, 73040, Ukraine 